OnLine Journal of Biological Sciences 8 (1): 19-24, 2008

ISSN 1608-4217

(C) 2008 Science Publications

\title{
Plants Responses to Nutrients Follow the Saturation Kinetic Typical of Enzyme Systems: Biological, Economical and Environmental Implications
}

\author{
R.P. Lana \\ Department of Animal Science, Federal University of Viçosa, Av. Peter Henry Rolfs, s/n, \\ 36571-000, Viçosa, Minas Gerais, Brazil
}

\begin{abstract}
Agricultural efficiency has been associated with high plant productivity. However, it is dependent on fertilizers, which are nonrenewable resources. Crop production response to fertilizers is hyperbolic, following the Michaelis-Menten model and the law of diminishing return. Data of crop production (barley, bean, corn, cotton, soybean and wheat) as a function of nitrogen, phosphorus, and potassium fertilization were analyzed by Lineweaver-Burk data transformation (L-B), that allows to calculate the amount of a specific nutrient needed to reach half $\left(\mathrm{k}_{\mathrm{s}}\right)$ or other percentages of the theoretical maximum response $\left(\mathrm{k}_{\max }\right)$ and the efficiency of fertilizer use $(\mathrm{kg}$ of grain $/ \mathrm{kg}$ of fertilizer). The efficiency of fertilizer use presented exponential decay by increasing fertilization: 55 to 3; 63 to 5; and 47 to $1 \mathrm{~kg}$ of corn $/ \mathrm{kg}$ of fertilizer, by increasing nitrogen, $\mathrm{P}_{2} \mathrm{O}_{5}$ and potassium from 40 to 200 ; 40 to 200 ; and 60 to $300 \mathrm{~kg} \mathrm{ha}^{-1}$, respectively. The L-B can be an alternative to the linearplateau and polynomial regression methods of recommendation of plant fertilization, in which the fertilizers recommendation should be based on their efficiency of use, avoiding losses of nutrients, environmental pollution, waste of nonrenewable natural resources, and reducing productive costs.
\end{abstract}

Key Words: Crop, fertilizer, lineweaver-burk, michaelis-menten, yield

\section{INTRODUCTION}

Productive efficiency has been associated with increase in productivity. The mean productivity of corn grain and soybean in Brazil is 2,770 and 2,430 $\mathrm{kg} \mathrm{ha}^{-1}$, respectively and the highest commercial productivity is 11,000 and $4,800 \mathrm{~kg} \mathrm{ha}^{-1}$, respectively ${ }^{[7]}$. Based on this information, researchers believe that there is a good potential to be achieved by the producers.

Crop production responds in a curvilinear fashion to fertilizer (hyperbolic function) and the maximum profitability is believed to be when the plants do not respond anymore to fertilization ${ }^{[8]}$. The level of fertilizer recommendation is normally obtained by linear response plateau or quadratic regression, considering the maximum plant performance.

The use of fertilizers in agriculture has to be evaluated with caution, since fertilization represents around $42 \%$ of productive costs, the marginal increase in plant growth response reduces as the amount of fertilization increases ${ }^{[6]}$ and the increase in fertilization leads to soil and water pollution and waste of nonrenewable natural fertilizer resources.

Lana et al. ${ }^{[6]}$ applied the Lineweaver-Burk data transformation to explain the animal and plant performance as a function of nutrient supply and reported that it follows a Michaelis-Menten relationship. This procedure allows obtaining the kinetic constants of the Michaelis-Menten model, $\mathrm{k}_{\max }$ (theoretical maximum production) and $\mathrm{k}_{\mathrm{s}}$ (amount of nutrient needed to reach half theoretical maximum production).

The Lineweaver-Burk data transformation makes also possible to calculate the amount fertilizer needed to reach other percentages of the theoretical maximum response $^{[6]}$ and it has important applications in rational fertilizer recommendations in the future.

This study has as objective to use the LineweaverBurk data transformation to evaluate the use of fertilizer in crop production in the tropics.

\section{MATERIALS AND METHODS}

Data of barley (Hordeum vulgare), corn (Zea mays), cotton (Gossipium hirsutum) and bean (Phaseolus vulgaris) responses to nitrogen fertilization were obtained from some publications ${ }^{[2,11,12]}$; data of corn (Zea mays), soybean (Glycine max) and wheat (Triticum aestivum) responses to phosphorus fertilization were obtained from Oliveira et al. ${ }^{[9]}$ and data of corn (Zea mays) response to potassium fertilization was obtained from Ritchey et al. ${ }^{[10]}$.

Linear regressions of the reciprocal of plant responses as a function of the reciprocal of nutrient 
supply were developed. This technique is called the Lineweaver-Burk equation ${ }^{[1]}$ and the model is as following:

$$
1 / \mathrm{Y}=\mathrm{a}+\mathrm{b} \times(1 / \mathrm{X})
$$

Where:

$\mathrm{Y}=$ Plant responses (grain yield, metric ton/ha)

$\mathrm{a}=$ Intercept

$\mathrm{b}=$ Coefficient of the linear regression

$\mathrm{X}=$ Amount of nutrient $\left(\mathrm{kg} \mathrm{ha}^{-1} \mathrm{year}^{-1}\right)$

The theoretical maximum grain yields $\left(\mathrm{k}_{\max }\right)$ were obtained by the reciprocal of the intercept (1/a). The amount of nutrient $(\mathrm{X})$ needed to reach $0.50\left(\mathrm{k}_{\mathrm{s}}\right), 0.60$, $0.70,0.80,0.90$ and 0.95 of the theoretical maximum response was obtained from the model presented above by replacing $\mathrm{Y}$ by $1 / \mathrm{a} \mathrm{x}$ proportion response $\mathrm{x} 0.01$. The amount of nutrient needed to reach half theoretical maximum response $\left(\mathrm{k}_{\mathrm{s}}\right)$ can also be obtained, dividing the coefficient of the linear regression by the intercept (b/a).

The efficiency of fertilizer utilization was calculated by dividing the accretion in crop response $\left(\mathrm{Y}_{2}-\mathrm{Y}_{1}\right)$ by the increase in fertilization $\left(\mathrm{X}_{2}-\mathrm{X}_{1}\right)$, from the specified level of fertilizer to the previous one.

\section{RESULTS}

The responses in crop production by nitrogen, phosphorus and potassium fertilization are shown in Fig. 1, in which in all cases there was a curvilinear relationship.

Linear regressions of the reciprocal of crop production as a function of the reciprocal of nitrogen, phosphorus and potassium fertilization, called Lineweaver-Burk data transformation, were developed. The constants of linear regressions (intercept and coefficient) are found in Table 1, in which all regressions showed a good fit to the data $\left(\mathrm{r}^{2}\right.$ from $0.96-$ $0.99)$.

The estimated crop productions by the LineweaverBurk data transformation as a function of fertilization (Fig. 2) were similar to the observed values (Fig. 1), except in very low levels of fertilization. In this case, the observed values were higher due to the residual effects of the minerals present in the soil.

The amount of fertilizer needed to reach half theoretical maximum response $\left(\mathrm{k}_{\mathrm{s}}=\mathrm{b} / \mathrm{a}\right)$ were 36,20 , 12 and $7 \mathrm{~kg}$ of nitrogen $\mathrm{ha}^{-1}$ year $^{-1}$ for barley $(H$. vulgare), corn (Z. mays), cotton (G. hirsutum) and bean

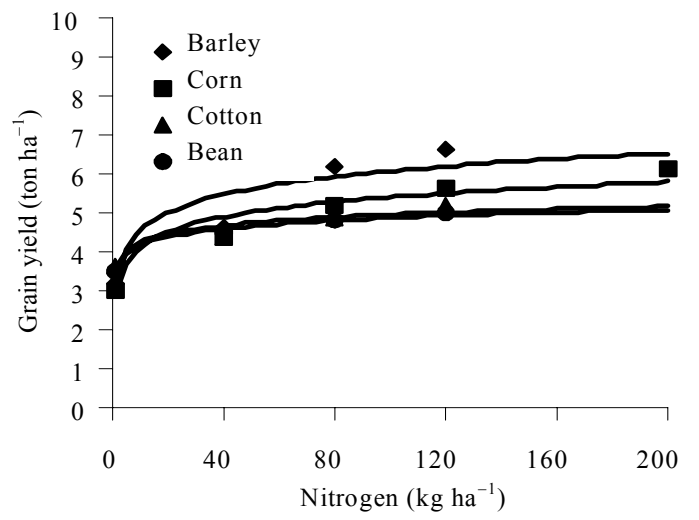

(a)

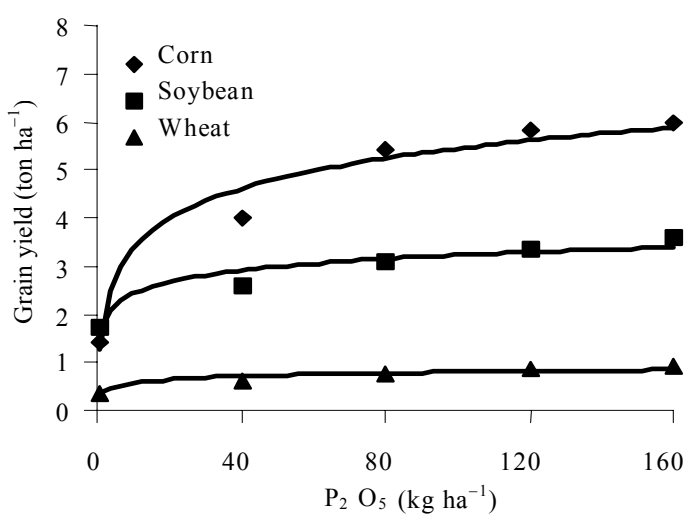

(b)

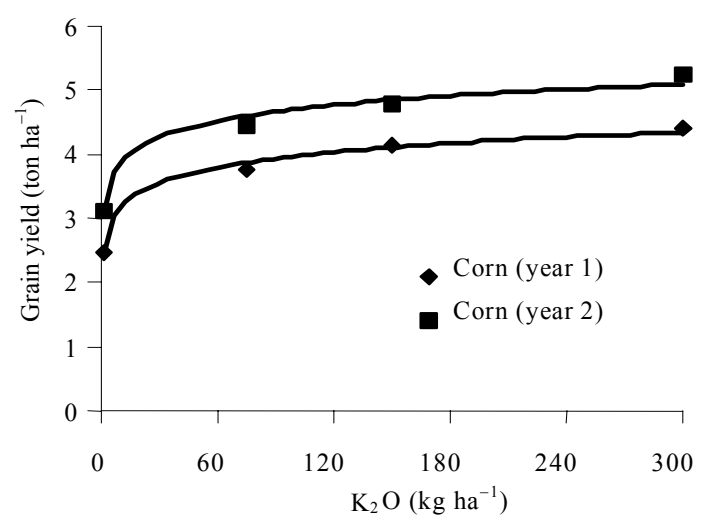

(c)

Fig. 1: Crop production as a function of nitrogen (A), phosphorus (B) and potassium (C) fertilization

(P. vulgaris), respectively; 34,22 and $31 \mathrm{~kg}$ of $\mathrm{P}_{2} \mathrm{O}_{5}$ $\mathrm{ha}^{-1}$ year $^{-1}$ for corn, soybean (G. max) and wheat ( $\mathrm{T}$. aestivum), respectively; and 16 and $20 \mathrm{~kg}$ of $\mathrm{K}_{2} \mathrm{O} \mathrm{ha}^{-1}$ year for corn in the year 1 and 2, respectively. These values were calculated from the constants of the linear regressions shown in Table 1. 
OnLine J. Biol. Sci., 8 (1): 19-24, 2008

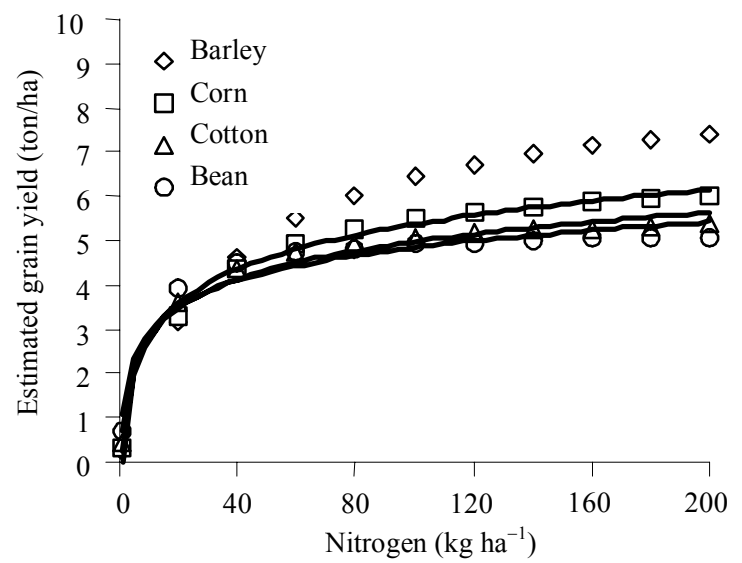

(a)

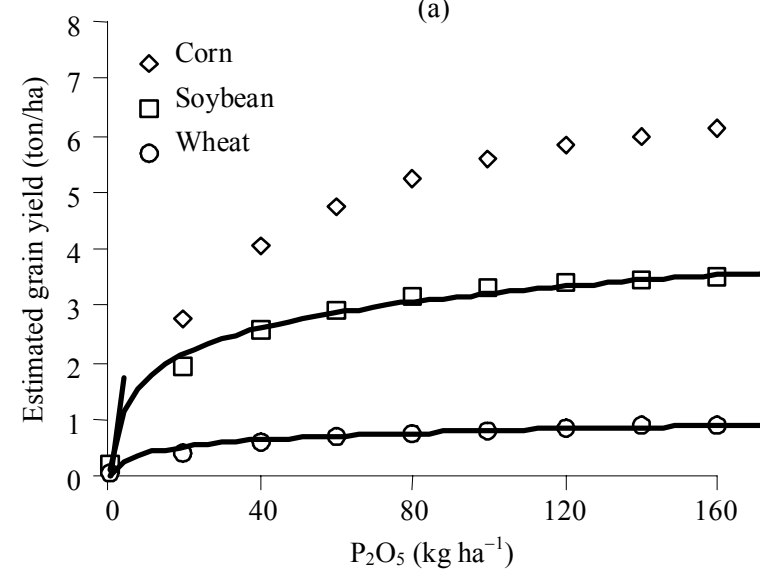

(b)

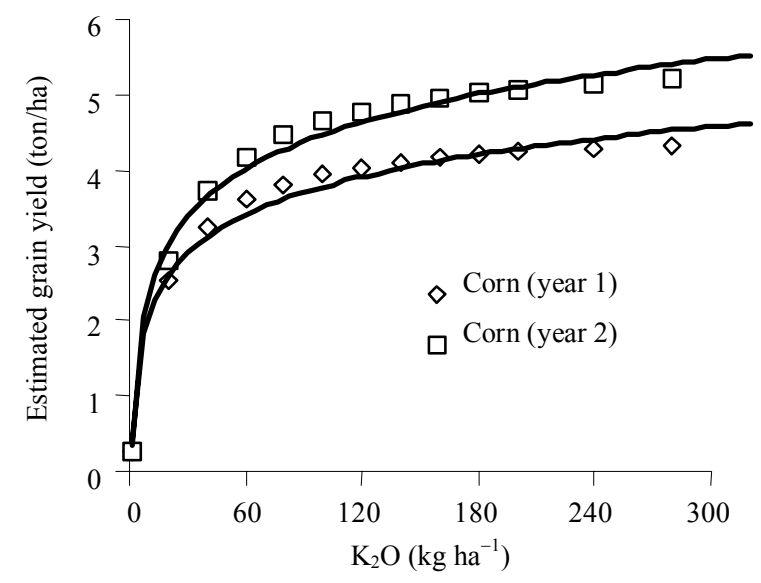

(c)

Fig. 2: Estimated crop production, by Lineweaver-Burk data transformation, as a function of nitrogen (A), phosphorus (B) and potassium (C) fertilization

The amounts of fertilizer needed to reach from very low to high theoretical maximum responses are
Table 1: Constants of linear regressions of the reciprocal of crop production $\left(x 1,000 \mathrm{~kg} \mathrm{ha}^{-1}\right)$ as a function of reciprocal of amount of fertilization $\left(\mathrm{kg} \mathrm{ha}^{-1} \mathrm{year}^{-1}\right)$

\begin{tabular}{llll}
\multicolumn{4}{c}{ amount of fertilization $\left(\mathrm{kg} \mathrm{ha}^{-1} \mathrm{year}^{-1}\right)$} \\
\hline & Intercept (a) & Coefficient (b) & $\mathrm{r}^{2}$ \\
\hline Nitrogen (N) fertilization & & & \\
Barley (Hordeum vulgare) & 0.1145 & 4.0761 & 0.99 \\
Corn (Zea mays) & 0.1513 & 3.0850 & 0.99 \\
Cotton (Gossipium hirsutum) & 0.1767 & 2.0419 & 0.99 \\
Bean (Phaseolus vulgaris) & 0.1906 & 1.2821 & 0.98 \\
Phosphorus ( $\mathrm{P}_{2} \mathrm{O}_{5}$ ) fertilization & & & \\
$\quad$ Corn (Zea mays) & 0.1344 & 4.5450 & 0.99 \\
$\quad$ Soybean (Glycine max) & 0.2495 & 5.4791 & 0.99 \\
$\quad$ Wheat (Triticum aestivum) & 0.9383 & 29.4580 & 0.99 \\
Potassium (K $\left.\mathrm{K}_{2} \mathrm{O}\right)$ fertilization & & & \\
$\quad$ Corn (Zea mays) - year 1 & 0.2183 & 3.5655 & 0.98 \\
$\quad$ Corn (Zea mays) - year 2 & 0.1787 & 3.6273 & 0.96 \\
\hline
\end{tabular}

Table 2: Profitability of corn production as a function of nitrogen fertilization

\begin{tabular}{|c|c|c|c|c|c|}
\hline $\begin{array}{l}\text { Nitrogen } \\
\left(\mathrm{kg} \mathrm{ha}^{-1}\right)\end{array}$ & $\begin{array}{l}\text { Estimated corn } \\
\text { yield }(\mathrm{x} \\
\left.1,000 \mathrm{~kg} \mathrm{ha}^{-1}\right)\end{array}$ & $\begin{array}{l}\text { Gross } \\
\text { income }{ }^{1} \\
\text { (US\$/ha) }\end{array}$ & $\begin{array}{l}\text { Nitrogen } \\
\text { cost }^{2} \\
\text { (US\$/ha) }\end{array}$ & $\begin{array}{l}\text { Nitrogen }+ \\
\text { fixed costs } \\
\text { (US } \$ / \mathrm{ha})\end{array}$ & $\begin{array}{l}\text { Net } \\
\text { income } \\
\text { (US\$/ha) }\end{array}$ \\
\hline 20 & 3.3 & 311 & 44 & 199 & 112 \\
\hline 40 & 4.4 & 414 & 89 & 244 & 170 \\
\hline 60 & 4.9 & 462 & 133 & 288 & 174 \\
\hline 80 & 5.3 & 499 & 177 & 332 & 167 \\
\hline 100 & 5.5 & 518 & 222 & 377 & 141 \\
\hline 120 & 5.6 & 528 & 266 & 421 & 107 \\
\hline 140 & 5.8 & 546 & 311 & 466 & 80 \\
\hline 160 & 5.9 & 556 & 355 & 510 & 46 \\
\hline 180 & 5.9 & 556 & 400 & 555 & 1 \\
\hline 200 & 6.0 & 565 & 444 & 599 & -34 \\
\hline
\end{tabular}

shown in Fig. 3. Bean was the most responsive to low nitrogen fertilization (low $\mathrm{k}_{\mathrm{s}}$ ) and barley was the least responsive, in which more nitrogen was necessary to reach half theoretical maximum response. Soybean was more responsive than the cereals, corn and wheat, to phosphorus fertilization.

The efficiency of fertilizer use decreased drastically by increasing fertilization in all cases (Fig. 4). The efficiency represents the accretion in crop production per unit of increase in fertilization.

The ideal level of fertilization is in the highest benefit/cost ratio, which is lower than the maximum plant response to fertilization. In the case of corn fertilized with nitrogen, the highest benefit/cost ratio was obtained with $55 \mathrm{~kg}$ of nitrogen fertilization (Table 2) in which there was a greater vertical distance between the curve of gross income and fertilizer + fixed costs (Fig. 5). This happened when the efficiency of fertilizer use was still high (Fig. 4). Therefore, the recommendation of fertilization should vary from one year to another, depending on the price of the fertilizer, the expected crop commercialization values and the efficiency of fertilizer use (plant response). 
OnLine J. Biol. Sci., 8 (1): 19-24, 2008

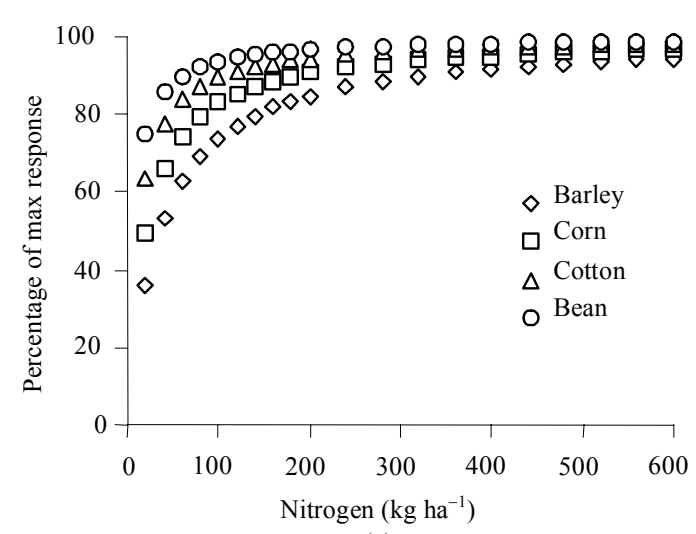

(a)

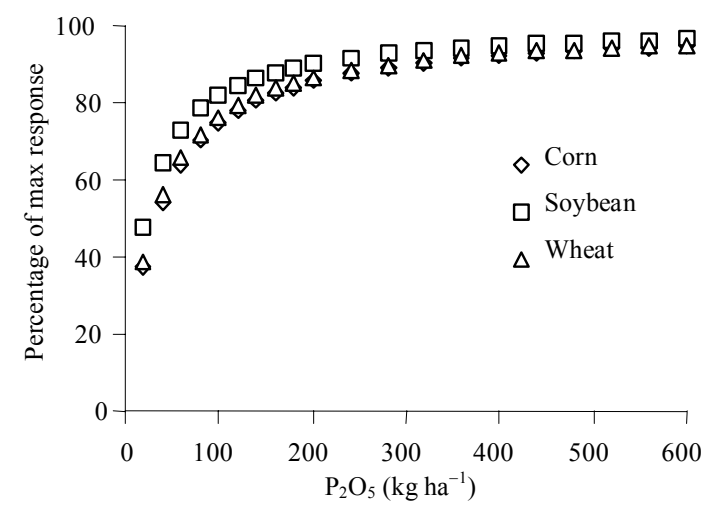

(b)

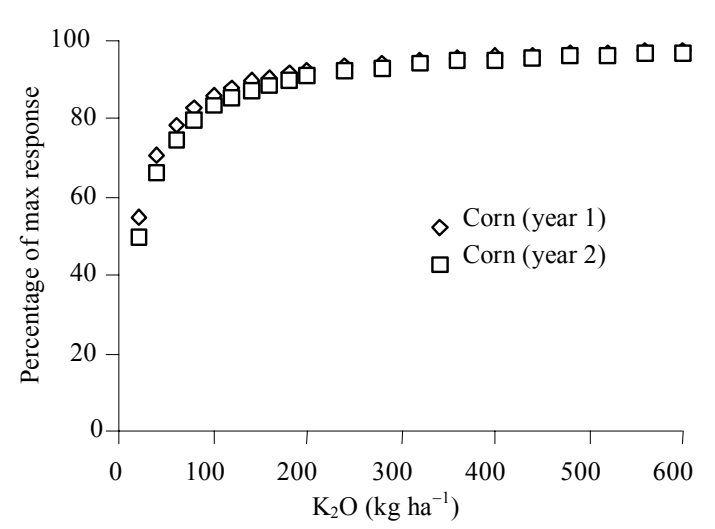

(c)

Fig. 3: Percentage response of crop production by nitrogen (a), phosphorus (b) and potassium (c) fertilization. The data was calculated from the estimated crop production by Lineweaver-Burk data transformation

\section{DISCUSSION}

The Michaelis-Menten model is the one that best accounts for the curvilinear relationship of plant responses to fertilization ${ }^{[6]}$. The model of Michaelis-

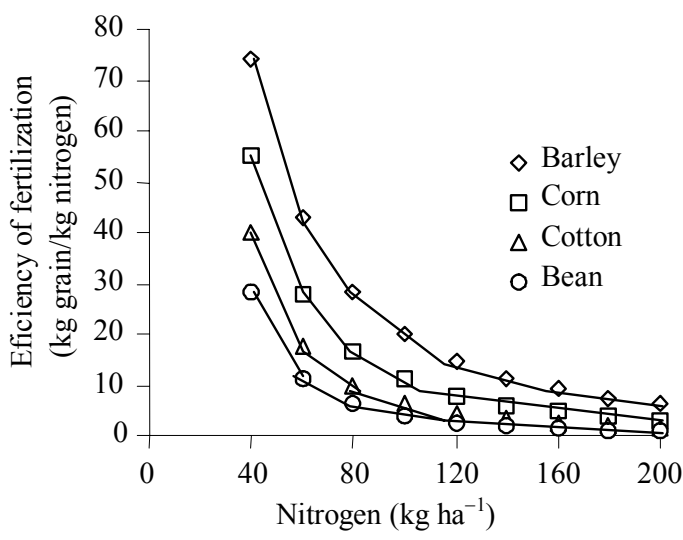

(a)
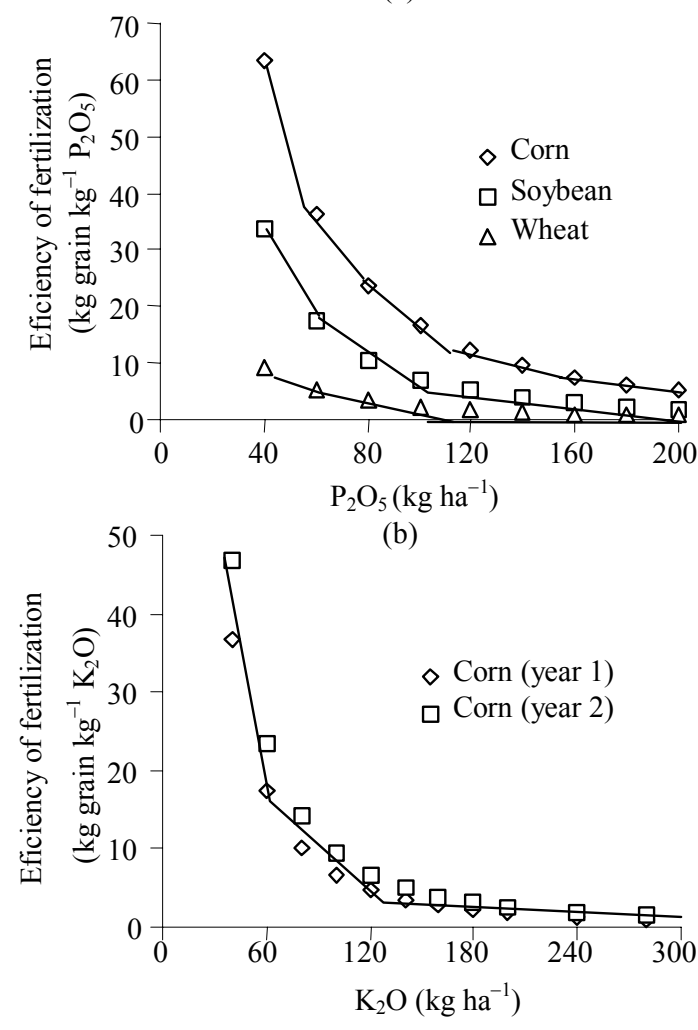

(c)

Fig. 4: Efficiency of nitrogen (a), phosphorus (b) and potassium (c) fertilizer's use, considering the estimated increment in crop production, by Lineweaver-Burk data transformation, comparing the specified level of fertilizer with the previous one

Menten is the following: $\mathrm{k}=\left(\mathrm{k}_{\max } \times \mathrm{S}\right) /\left(\mathrm{k}_{\mathrm{s}}+\mathrm{S}\right)$, where $\mathrm{k}$ is specific crop production $\left(\mathrm{kg} \mathrm{ha}^{-1} \mathrm{year}^{-1}\right), \mathrm{k}_{\max }$ is the theoretical maximum crop production, $\mathrm{S}$ is fertilizer utilization $\left(\mathrm{kg} \mathrm{ha}^{-1}\right.$ year $\left.{ }^{-1}\right)$ and $\mathrm{k}_{\mathrm{s}}$ is the amount of 


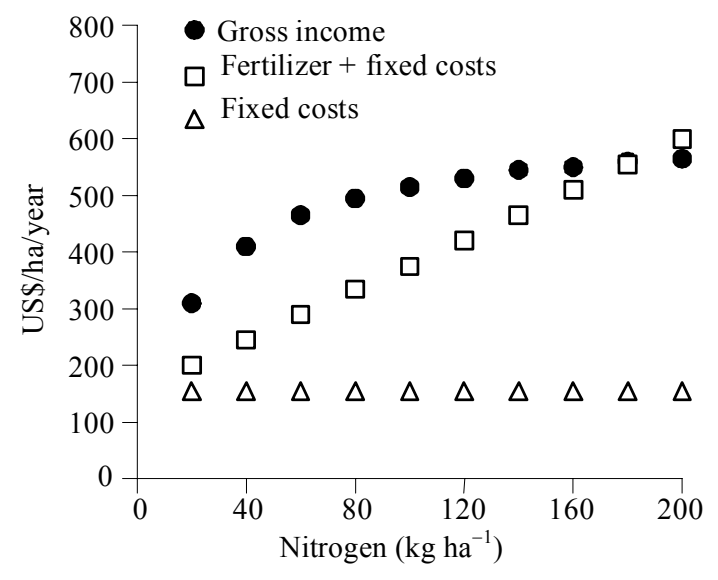

Fig. 5: Costs and gross income of corn production as a function of nitrogen fertilization. The corn production was estimated by Lineweaver-Burk data transformation

fertilizer needed to reach half theoretical maximum crop production.

The use of the Lineweaver-Burk data transformation allows explaining the animal and plant performance as a function of nutrient supply. This procedure allows obtaining the kinetic constants of the Michaelis-Menten model, $\mathrm{k}_{\mathrm{s}}$ and $\mathrm{k}_{\max }$. In addition, the Lineweaver-Burk data transformation makes possible to calculate the amount of a specific nutrient (x) needed to reach other percentages of the theoretical maximum response (Fig. 3), by replacing y by $1 /$ (a x (proportion response/100)) in the linear models of the transformed data $^{[6]}$.

This procedure can be an alternative to the broken line and polynomial regressions for recommendation of plant fertilization. Instead of calculating the amount of fertilizer to reach maximum response, it will be possible to calculate the amount of fertilizer as a function of efficiency of nutrient utilization. This is of large economic and environmental importance, since that loss of nutrients contributes to environmental pollution, waste of nonrenewable natural resources and increase in productive costs.

According to Oliveira et al. ${ }^{[9]}$, the economical level of fertilization depends on the nutrient content in the soil that determines the culture response to fertilization, the fertilizer cost, the production-selling price and the residual effect of fertilizer in the subsequent years. Normally, the culture yield that gives the maximum economical efficiency is between 80 and $95 \%$ of the culture maximum performance.

However, the profitability of cultures fertilization depends on the efficiency of fertilization use, expressed in accretion of crop production per kilogram of fertilizer and the favorable ratio of commercialized crop production to fertilizer cost (Table 2). The benefit/cost relation should consider that by increasing productivity, more crops are available for commercialization and by increasing products offer in the market, prices normally go down.

The highest benefit/cost ratio is the level of fertilization that makes a greater vertical distance between the curve of gross income and fertilizer+fixed costs (Fig. 5). This was verified with 55 (Table 2), 120 and $80 \mathrm{~kg}$ of nitrogen $\mathrm{ha}^{-1}$ for corn, cotton and bean, respectively; 120 and $120 \mathrm{~kg}$ of $\mathrm{P}_{2} \mathrm{O}_{5} \mathrm{ha}^{-1}$ for corn and soybean, respectively and 100 and $120 \mathrm{~kg}_{\text {of }} \mathrm{K}_{2} \mathrm{O} \mathrm{ha}^{-1}$ for corn in two consecutive years. These levels of fertilization are enough for 73, 91 and 92,78 and 84 and 86 and $86 \%$ of theoretical maximum crop production (Fig. 3), respectively. The theoretical maximum crop production varied from $73-92 \%$ (mean of $84 \%$ ), which is lower than $80-95 \%$ of the culture maximum performance suggested by Oliveira et al. ${ }^{[9]}$.

Productive efficiency has been associated with increase in productivity, in which the highest commercial yields for corn and soybean are two and four fold greater, respectively, than the mean productivity in Brazil ${ }^{[7]}$. However, the efficiency of fertilization use and decreases in crop commercialization prices by increasing productivity has to be considered in fertilizer recommendations. This information can explain why it is not feasible to increase the mean productivity to reach the highest observed commercial productivity.

Another important issue that have to be considered is that increase in fertilization leads to soil and water pollution and waste of nonrenewable natural fertilizer resources. The data analyzed show clearly that plant response to fertilization decrease drastically by increasing fertilization (Fig. 4). In addition, Lana et $a l .{ }^{[6]}$ described that the low availability of nutrients in the poor soil of the tropics cause a high plant response to low level of fertilization.

The world phosphate reserves that can be explored at low cost are enough for 100 years $^{[3]}$. The world potassium reserves are enough for 200 years and the situation is even worse for the micronutrients, in which the zinc and copper world reserves are enough for 60 years. According to Herring and Stowasser ${ }^{[4]}$, by 2020 the rock phosphorite may be the keystone resource of the world economy. Therefore, knowledge about the efficiency of fertilizer utilization in agriculture will play an important role in the political decisions about use of nonrenewable natural resources in the future. 
Phosphorus and nitrogen fertilization causes decreases in water oxygenation due to excessive increase in toxic algae population in the oceans. Excess of nitrogen contributes to environmental pollution through its emissions as nitrogen oxide, nitrous oxide and ammonia in air and nitrates on soil and water. Nitrate pollution is an actual worry in Europe and North America $^{[5]}$. In the same way, knowledge about the efficiency of fertilizer utilization in agriculture will play an important role in the political decisions about the rational use of fertilizers in the future.

\section{CONCLUSION}

The plant response to fertilization is curvilinear in which this effect is accentuated at very low level of fertilization.

The Michaelis-Menten model is the one that best account for efficient fertilizer utilization and can be used for fertilizer recommendation for a range of desirable plant performance.

The recommendation of fertilization should vary from one year to another, depending on the price of fertilizer, the expected crop commercialization values and the efficiency of fertilizer use (plant response).

Increase in fertilization leads to decrease in the efficiency of fertilizer use, waste of nonrenewable natural resources, environmental pollution and increase in productive costs.

\section{REFERENCES}

1. Champe, P.C. and R.A. Harvey, 1994. Biochemistry. 2nd Edn., ISBN 0-397-51091-8. J.B. Lippincott Company, Philadelphia.

2. Guerra, A.F., D.B. Silva and G.C. Rodrigues, 2000. Management of irrigation and nitrogen fertilization of bean in tropical savanna. Pesquisa Agropecuária Brasileira, 35: 1229-1236.

http://www.scielo.br/scielo.php?pid=S0100204X2000000600020\&script $=$ sci_arttext\&tlng=pt doi: $10.1590 / S 0100-204 X 2000000600020$

3. Herring J.R. and R.J. Fantel, 1993. Phosphate rock demand into the next century: Impact on world food supply. Nonrenewable Resour., 2: 226-246.
4. Herring J.R. and W.F. Stowasser, 1991. Phosphateour's nation most important agricultural mineral commodity and its uncertain future. Geological Soc. Am., Abstracts with Programs, 23: 299-300.

5. Kebreab, E., J. France, J.A.N. Mills, R. Allison and J. Dijkstra, 2002. A dynamic model of $\mathrm{N}$ metabolism in the lactating cow and an assessment of impact on $\mathrm{N}$ excretion on the environment. J. Anim. Sci., 80: 248-259. http://jas.fass.org/cgi/reprint/80/1/248

6. Lana, R.P., R.H.T.B. Goes, L.M. Moreira, A.B. Mâncio, D.M. Fonseca and L.O. Tedeschi, 2005. Application of Lineweaver-Burk data transformation to explain animal and plant performance as a function of nutrient supply. Livestock Prod. Sci. (http://www.elsevier.com), 98: 219-224.

7. Lobato, E. and D.M.G. Sousa, 2004. Soil fertility and maximum productive efficiency. In: Savannasoil correction and fertilization, 2nd Edn., ISBN 85-7383-230-4 (eds D.M.G. Sousa and E. Lobato) EMBRAPA, Brasília, DF, Brazil. pp: 257-282.

8. Malavolta, E., 1989. ABC of fertilization, 5th Edn., ISBN 85-318-0002-1. Ceres, São Paulo, SP, Brazil, pp: 246.

9. Oliveira, A.J., S. Lourenço and W.J. Goedert, 1982. Phosphate fertilization in Brazil. EMBRAPA-DID, Brasília, DF, Brazil. pp: 70-73.

10. Ritchey, K.D., D.M.G. Sousa and E. Lobato, 1979. Potassium in tropical savanna soil. I. Response to potassium fertilization. Brazilian Journal of Soil Science (http://www.journaldatabase.org/journals/ 521/Revista_Brasileira_de_Cie.html), Campinas, 3:29-32.

11. Sousa, D.M.G. and E. Lobato, 2004. Nitrogen fertilization. In: Savanna - soil correction and fertilization, 2nd Edn., ISBN 85-7383-230-4 (eds D.M.G. Sousa and E. Lobato) EMBRAPA, Brasília, DF, Brazil. pp: 129-145.

12. Suhet, A.R., J.R.R. Peres and M.A.T. Vargas, 1986. Nitrogen. In: Tropical savanna soils: technology and management strategies (ed. W.J. Goedert) pp.167-202. Nobel, São Paulo, SP, Brazil. 